\title{
PERLINDUNGAN HUKUM NASABAH PERBANKAN DALAM TRANSAKSI ELEKTRONIK
}

\author{
Luthfi Syaifuddin, Paramita Prananingtyas \\ Program Studi Magister Kenotariatan, \\ Fakultas Hukum, Universitas Diponegoro \\ Email: lutfia@gmail.com
}

\begin{abstract}
Electronics is now a necessity for modern society to use it as a means of payment. In the trade business for example, technological advances have given rise to the method of transactions known as E-Commerce (Electronic Commerce). The use of internet facilities is a technological advancement that can be said to support the overall spectrum of commercial activities. The method of approach used in this study is empirical juridical, which uses the primary data of BNI leadership Kcp Ngaliyan through interviews and secondary data through library research. All data collected was analyzed using a qualitative method then presented descriptively so that a conclusion was obtained. Based on the results of the study Legal protection for customers of EBanking users has not run properly. Legal safeguards against customers of E-Banking users can only be realized with the participation of various parties. The customer must be more proactive in knowing his rights and obligations and also the Bank should be more open and improve its performance. Also Electronic Information and Transactions require a more representative formulation that can reach all forms of crime using E Banking
\end{abstract}

Keywords: Customer Legal Protection, Electronic Transactions

\begin{abstract}
Abstrak
Elektronik saat ini merupakan suatu kebutuhan masyarakat modern untuk menggunakannya sebagai sarana pembayaran. Dalam bisnis perdagangan misalnya, kemajuan teknologi telah melahirkan metode bertransaksi yang dikenal dengan istilah E-Commerce ( Electronic Commerce ). Penggunaan sarana internet merupakan suau kemajuan teknologi yang dapat dikatakan menunjang secara keseluruhan spectrum kegiatan komersial.Metode pendekatan yang digunakan dalam penelitian ini adalah yuridis empiris, yang menggunakan data primer pimpinan BNI Kcp Ngaliyan melalui wawancara dan data sekunder melalui studi kepustakaan. Seluruh data yang tekumpul dianalisis menggunakan metode kualitatif kemudian dipaparkan secara deskriptif sehingga diperoleh suatu kesimpulan. Berdasarkan pada hasil penelitian Perlindungan hukum terhadap nasabah pengguna E-Banking belum berjalan sebagaimana mestinya. Upaya Perlindungan hukum terhadap nasabah pengguna E-Banking hanya dapat terwujud dengan adanya partisipasi dari berbagai pihak. Pihak nasabah harus bersikap lebih proaktif untuk mengetahui hak dan kewajibannya dan juga pihak Bank hendaknya lebih bersikap terbuka dan memperbaiki kinerjanya. Juga Informasi dan Transaksi Elekronik diperlukan perumusan yang lebih representatif yang dapat menjangkau semua bentuk kejahatan dengan menggunakan $\mathrm{E}$ Banking.
\end{abstract}

Kata kunci : Perlindungan Hukum Nasabah, Transaksi Elektronik 


\section{A. Pendahuluan}

Perkembangan teknologi dan internet sudah sangat pesat pada masa ini, hal tersebut menambah kenyamanan masyarakat luas di segala bidang. Salah satu sektor yang terpengaruh oleh perkembangan teknologi informasi dan komunikasi adalah perbankan, sub sektor ekonomi yang memobilisasi dana masyarakat. Teknologi informasi dan komunikasi telah melahirkan inovasi perbankan serta memberikan dampak efisien dan ektivitas yang luar biasa. ${ }^{1}$ Saat ini media elektronik menjadi salah satu media andalan untuk melakukan komunikasi dan bisnis. Industri perbankan saat ini pun sudah mengandalkan kegiatan operasionalnya berbasiskan pada teknologi informasi salah satu bentuknya berupa internet banking. Produk dan jasa yang dilakukan oleh bank harus sesuai dengan ketentuan yang ada berdasarkan jenis banknya sebagaimana yang diatur dalam Undang-Undang Nomor 7 tahun 1992 Tentang Perbankan Sebagaimana Telah Diubah Dengan Undang-Undang Nomor 10 Tahun 1998.

Sejalan dengan kebutuhan akan pelayanan telekomunikasi yang semakin meningkat dikarenakan tuntutan kebutuhan pengguna dimasa depan yang semakin meningkat pula. Sistem komunikasi bergerak diyakini akan memegang peranan yang semakin penting dalam memenuhi kebutuhan telekomunikasi.Adanya fasilitas elektronik banking semakin memudahkan para nasabah bank untuk melakukan transaksi perbankan tanpa harus datang ke bank secara langsung.

Konsep elektronik pada perkembangannya banyak diadopsi oleh industri perbankan konvensional. Elektronik khususnya di Indonesia memiliki perkembangan yang sangat pesat. ${ }^{2}$ Hal ini tidak terlepas dari keuntungan yang dapat diraih dengan memanfaatkan layanan elektronik. Ada beberapa alasan yang dapat dikemukakan bahwa industri perbankan saat ini banyak mengadopsi konsep elektronik, yaitu: ${ }^{3}$

a. Industri perbankan berkeinginan memperluas jangkauan akses pasarnya

b. Industri perbankan berkeinginan untuk meningkatkan mutu dan kualitas pelayanan terhadap para nasabahnya

c. Penerapan elektronik dapat dijadikan sebagai sarana strategis untuk melakukan kompetisi antar bank yang terasa sangat ketat.

\footnotetext{
${ }^{1}$ Resa Raditio, Aspek Hukum Transaksi Elektronik (Jakarta: Graha Ilmu, 2014).

${ }^{2}$ Brian Ami Prasetyo, 'Diskusi Permasalahan Hukum Terkait Internet Banking Dan Solusi Penyelesaiannya', Buletin Hukum Perbankan Dan Kebanksentralan, Vol.3 No.2 (2005), 65-66.

${ }^{3}$ Budi Raharjo, Keamanan Informasi Berbasis Internet (Bandung: PT.Insan Indonesia, 2005).
} 
Indonesia adalah negara keempat di dunia yang penduduknya paling banyak menggunakan layanan internet. ${ }^{4}$ Hal ini jugalah yang turut memacu bank-bank di Indonesia untuk melahirkan layanan elektronik sendiri. Penggunaan elektronik di Indonesia belum dimanfaatkan secara penuh oleh bank-bank nasional di Indonesia. Sebagai contoh yaitu bank Bank Internasional Indonesia (BII) yang mengklaim dirinya sebagai bank nasional penyelenggara internet banking yang pertama di Indonesia yakni pada tahun 2000 dengan situsnya www.bankbii.co.id. BII pada saat itu menggunakan media internet baru sebatas sebagai sarana untuk mempromosikan produk-produk bank BII. Hal ini terjadi bisa saja terjadi mengingat ketersediaan dana untuk pengadaan teknologi yang berkaitan dengan elektronik. Selain itu, juga menyangkut kesiapan sumber manusianya, sehingga penerapan elektronik tidak dapat di implementasikan secara penuh. ${ }^{5}$ Bank Central Asia (BCA) ketika meluncurkan layanan internet banking, yaitu www.klikbca.com, barulah penerapan internet banking ini mulai dijalankan secara penuh, dimana pihak bank BCA sebagai penyedia layanan elektronik, dalam menyediakan layanan, tidak saja hanya berkaitan dengan promosi produk-produknya serta memberikan kesempatan kepada nasabah untuk melakukan transaksi-transaksi secara online melalui media internet.Setelah bank BCA meluncurkan layanan internetnya, bank-bank nasional lainnya pun kemudian ikut meluncurkan layanan internet banking, seperti www.bni.co.id, www.bankmandiri.co.id, dan sebagaimya. Hal ini terjadi karena menyadari Indonesia menduduki peringkat keempat didunia yang penduduknya paling banyak menggunakan media internet, sehingga layanan internet banking banyak digunakan oleh nasabah untuk melakukan transaksi online melalui media internet.

Sejalan dengan kemudahan yang didapat dari penggunaan elektronik ada juga resiko yang di dapat dalam penggunaanya layanan ini, antara lain banyak terjadi pelanggaran hukum menyangkut data-data pribadi melalui internet dan juga mengenai resiko finasial yang diderita oleh nasabah bank dalam penggunaan elektronik karena ulah para pelaku kejahatan Teknologi Informasi (TI) tersebut menyebabkan industri perbankan harus mampu menyiapkan security features yang mampu menjaga tingkat kepercayaan masyarakat bahwa transaksi elektronik aman. ${ }^{6}$ Permasalahan yang ada di Indonesia untuk metode pembayaran elektronik tidak seperti di negara maju, banyak faktor yang akhirnya menjadi menghambat perkembangan elektronik banking yang ada di Indonesia. Metode pembayaran elektronik

\footnotetext{
${ }^{4}$ Ibid, hlm. 63

${ }^{5}$ Ibid, hlm.56

${ }^{6}$ Ibid, hlm. 67
} 
haruslah diperhitungkan dengan kondisi yang ada di Indonesia, yang pada nantinya sistem elektronik yang ada bisa lebih diterima oleh masyarakat Indonesia dengan kondisi saat ini yang beraneka ragam kompleksitas permasalahannya.

Masalah perlindungan hukum bagi konsumen perbankan khususnya dalam elektronik merupakan suatu hal yang sangat dilematis, sehingga sampai saat ini masalah perlindungan hukum bagi konsumen belum mendapatkan tempat yang baik dalam sistem Perbankan Nasional. ${ }^{7}$ Adanya keinginan dan desakan masyarakat untuk melindungi dirinya dari barang yang rendah mutunya telah memacu untuk memikirkan secara sungguh-sungguh usaha untuk melindungi konsumen ini, dan mulailah gerakan untuk merealisasikan cita-cita itu. Sebagaimana slogan hukum yang diungkapkan Satjipto Rahardjo "hukum dibuat untuk manusia bukan sebaliknya". 8 Di Indonesia, masalah perlindungan konsumen baru mulai terdengar pada tahun 1970 an. Ini terutama ditandai dengan lahirnya Yayasan Lembaga Konsumen (YLK) pada tanggal 11 Mei 1973. Secara historis, pada awalnya Yayasan ini berkaitan dengan rasa mawas diri terhadap promosi untuk memperlancar barang-barang dalam negeri. Atas desakan suara-suara dari masyarakat, kegiatan promosi ini harus diimbangi dengan langkah-langkah pengawasan, agar masyarakat tidak dirugikan dan kualitasnya terjamin.

Berdasarkan kompleksitas hubungan produsen dan konsumen, serta banyaknya mata rantai penghubung keduanya, maka dibutuhkan berbagai aspek hukum untuk melindungi konsumen sebagai pemakai akhir barang atau jasa secara adil. Perlindungan konsumen dimulai sejak awal proses produksi. Aspek hukum publik mendominasi sistem pengawasan terhadap mutu dan kesehatan serta ketepatan pemanfaatan bahan untuk sasaran produk. Setelah hubungan bersifat personal, hukum perdatalah yang akan lebih dominan dalam rangka melindungi kepentingan masing-masing pihak.

Sebagai pemakai barang/jasa, konsumen memiliki sejumlah hak dan kewajiban. Pengetahuan tentang hak-hak konsumen sangat penting agar orang bisa bertindak sebagai konsumen yang kritis dan mandiri. Tujuannya, jika ditengarai adanya tindakan yang tidak adil terhadap dirinya, ia secara spontan menyadari akan hal itu. Konsumen kemudian bisa bertindak lebih jauh untuk memperjuangkan hak-haknya. Dengan kata lain, ia tidak hanya tinggal diam saja ketika menyadari bahwa hak-haknya telah dilanggar oleh pelaku usaha. Berdasarkan UU Perlindungan konsumen pasal 4, hak-hak konsumen sebagai berikut :

\footnotetext{
${ }^{7}$ Wulanmas A.P.G, Buku Ajar Hukum Perbnkan (Yogyakarta: Genta Press, 2011).

${ }^{8}$ Romli Atmasasmita, Teori Hukum Integratif ,Rekonstruksi Terhadap Teori HUkum Pembangunan Dan Teori Hukum Progresif (Yogyakarta : Genta Publishing, 2012).
} 
1) Hak atas kenyamanan, keamanan, dan keselamatan dalam mengonsumsi barang/jasa.

2) Hak untuk memilih dan mendapatkan barang/jasa sesuai dengan nilai tukar dan kondisi serta jaminan yang dijanjikan.

3) Hak atas informasi yang benar, jelas dan jujur mengenai kondisi dan jaminan barang/jasa.

4) Hak untuk didengar pendapat keluhannya atas barang/jasa yang digunakan.

5) Hak untuk mendapatkan advokasi, perlindungan, dan upaya penyelesaian sengketa perlindungan konsumen secara patut.

6) Hak untuk mendapatkan pembinaan dan pendidikan konsumen.

7) Hak untuk diperlakukan atau dilayani secara benar dan jujur serta tidak diskrimainatif.

8) Hak untuk mendapatkan kompensasi, ganti rugi, atau penggantian, jika barang/jasa yang diterima tidak sesuai dengan perjanjian atau tidak sebagaimana mestinya.

9) Hak-hak yang diatur dalam ketentuan peraturan perundang-undangan lainnya.

Disamping hak-hak dalam pasal 4 juga terdapat hak-hak konsumen yang dirumuskan dalam pasal 7, yang mengatur tentang kewajiban pelaku usaha. Kewajiban dan hak merupakan antinomi dalam hukum, sehingga kewajiban pelaku usaha merupakan hak konsumen. selain hak-hak yang disebutkan tersebut ada juga hak untuk dilindungi dari akibat negatif persaingan curang. Hal ini dilatarbelakangi oleh pertimbangan bahwa kegiatan bisnis yang dilakukan oleh pengusaha sering dilakukan secara tidak jujur yang dalam hukum dikenal dengan terminologi " persaingan curang".

Kewajiban Konsumen Sesuai dengan Pasal 5 Undang-undang Perlindungan Konsumen, Kewajiban Konsumen adalah :

1) Membaca atau mengikuti petunjuk informasi dan prosedur pemakaian atau pemanfaatan barang dan/atau jasa, demi keamanan dan keselamatan;

2) Beritikad baik dalam melakukan transaksi pembelian barang dan/atau jasa;

3) Membayar sesuai dengan nilai tukar yang disepakati;

4) Mengikuti upaya penyelesaian hukum sengketa perlindungan konsumen secara patut. 
Undang-Undang Nomor 8 Tahun 1999 tentang Perlindungan Konsumen (UUPK) harusnya menjamin suatu Penyelenggaraan Perlindungan Konsumen dalam suatu produk hukum. Hal ini penting karena hanya hukum yang memiliki kekuatan untuk memaksa pelaku usaha untuk mentaatinya, dan juga hukum memiliki sanksi yang tegas. Mengingat dampak penting yang dapat ditimbulkan akibat tindakan pelaku usaha yang sewenangwenang dan hanya mengutamakan keuntungan dari bisnisnya sendiri, maka pemerintah memiliki kewajiban untuk melindungi konsumen yang posisinya memang lemah, disamping ketentuan hukum yang melindungi kepentingan konsumen belum memadai, ${ }^{9}$ khususnya dalam hal perlindungan hukum bagi nasabah bank selaku konsumen. Antara lain dengan adanya perjanjian kredit atau pembiayaan bank yang merupakan perjanjian standar (standard contract) termasuk dalam hal ini fasilitas elektronik.

Adapun ratio diundangkannya UUPK adalah dalam rangka menyeimbangkan daya tawar konsumen terhadap pelaku usaha dan mendorong pelaku usaha untuk bersikap jujur dan bertanggung jawab dalam menjalankan kegiatannya. UUPK mengacu pada filosofi pembangunan nasional, yakni bahwa pembangunan nasional termasuk pembangunan hukum memberikan perlindungan terhadap konsumen adalah dalam rangka membangun manusia Indonesia seutuhnya berlandaskan pada falsafah kenegaraan Republik Indonesia, yaitu dasar negara Pancasila dan Konstitusi negara UUD 1945. ${ }^{10}$

Posisi Konsumen sebagai pihak yang lemah juga diakui secara internasional sebagimana tercermin dalam Resolusi Majelis Umum Persatuan Bangsa Bangsa No.A/RES/39/248 tahun 1985, tentang Guidelines for Consumer Protection, yang menghendaki agar konsumen dimanapun mereka berada, dari segala bangsa, mempunyai hak-hak dasar tertentu, terlepas dari status sosialnya. Yang dimaksud dengan hak-hak dasar tersebut antara lain adalah hak untuk mendapatkan informasi yang jelas, benar, dan jujur, hak untuk mendapatkan keamanan dan keselamatan, hak untuk memilih, hak untuk didengar, hak untuk mendapatkan ganti rugi, hak untuk mendapatkan kebutuhan dasar manusia. PBB menghimbau seluruh anggotanya untuk memberlakukan hak-hak konsumen tersebut dinegaranya masing-masing. ${ }^{11}$ Pengaduan-pengaduan soal produk internet perbankan, seperti: ATM (Automatic Teller Machine), Kartu Kredit, dan aneka ragam jenis tabungan, termasuk keluhan produk perbankan terkait dengan janji hadiah dan iklan produk perbankan

${ }^{10}$ A.Z Nasution, 'Aspek Hukum PErlindungan Konsumen Tinjauan Singkat Undang - Undang No. 8 Tahun 1999', Media Hukum Dan Keadilan, Vol.II No. (2003).

${ }^{11}$ Gunawan widjaja dan Ahmad Yani, Hukum Tentang Perlindungan Konsumen (Jakarta: PT.Gramedia Pustaka Utama, 2003).
} 
merupakan hal yang sangat perlu untuk diteliti dan di kontruksikan kearah yang lebih mengedepankan nilai perlindungan hukum bagi nasabah selaku konsumen yang dijamin hakhak nya sebagai warga negara Indonesia. ${ }^{12}$

Berdasarkan latar belakang diatas penulis tertarik menulis sebuah tulisan ilmiah serta membahasnya dalam bentuk Tesis yang berjudul "Perlindungan Hukum Nasabah Perbankan Dalam Transaksi Elektronik”.

\section{B. Metode Penelitian}

Metode penelitian yang digunakan adalah yuridis empiris, dengan spesifikasi penelitiannya secara deskriptif analitis. Sumber dan jenis datanya berupa data primer dan data sekunder, lalu teknik pengumpulan data diperoleh melalui studi lapangan dan studi kepustakaan. Teknik analisa datanya menggunakan analisis kualitatif dengan pemikiran secara dedukatif-indukatif.

\section{Hasil dan Pembahasan}

Perkembangan teknologi informasi, telekomunikasi dan internet menyebutkan mulai munculnya aplikasi bisnis yang berbasis elektronik dalam dunia perbankan sendiri, pada umumnya memanfaatkan teknologi untuk mengakomodir kebutuhan berinteraksi antara perusahaan dengan nasabahnya. Elektronik Banking adalah salah satu jasa bank yang memungkinkan nasabah untuk memperoleh informasi, melakukan komunikasi dan melakukan transaksi perbankan melalui jaringan dan bukan merupakan bank yang hanya menyelanggarakan layanan perbankan melalui internet. Elektronik banking adalah fasilitas yang disediakan perusaahaan perbankan melalui benda elektronik (Handphone, Komputer dan Telephone) untuk memenuhi kebutuhan bertransaksi perbankan.

Reputasi sistem E-Banking didefinisikan sebagai penilaian pelanggan atas keistimewaan suatu sistem secara menyeluruh. Reputasi sistem E-Banking merupakan suatu proses evaluasi menyeluruh pelanggan mengenai kesempurnaan sistem. Reputasi sistem E-Banking selalu didefinisikan sebagai mutu peranti yang disusun dalam sistem itu sendiri, semakin baik dan memuaskan sistem yang di aplikasikan maka akan semakin bermutu piranti penyusunan sistem tersebut bagitu sebaliknya. Reputasi sistem E-Banking berpusat pada upaya pemenuhan kebutuhan dan keinginan serta keakuratan untuk mengimbangi harapan pelanggan.

Perlindungan Hukum Terhadap Nasabah Perbankan Dalam Praktik Transaksi Elektronik Berhubungan Dengan Tanggung Jawab Bank Atas Informasi Nasabah

Hukum Konsumen dan Hukum Perlindungan Konsumen merupakan istilah yang seringkali disamaartikan. Ada yang beranggapan bahwa hukum konsumen adalah juga hukum perlindungan

\footnotetext{
${ }^{12}$ Sudaryatmo, Hukum Dan Advokasi Konsumen (Bandung: PT.Citra Aditya Bhakti, 1999).
} 
konsumen. Namun ada pula yang membedakannya, dengan berpendapat bahwa baik mengenai substansi maupun mengenai penekanan luas lingkupnya adalah berbeda satu sama lain.

M. J. Leder menyatakan bahwa "In a sense there is no such creature as consumer law". Sekalipun demikian, secara umum sebenarnya hukum konsumen dan hukum perlindungan konsumen itu seperti yang dinyatakan oleh Lowe, yakni “....rules of law which recognize the bargaining weakness of the individual consumer and which ensure that weakness is not unfairly exploited". Karena konsumen berada pada posisi yang lemah, maka konsumen harus dilindungi oleh hukum, yang sifat dan tujuannya adalah memberikan perlindungan atau pengayoman terhadap masyarakat. Jadi, bisa dikatakan bahwa sebenarnya hukum konsumen dan hukum perlindungan konsumen adalah dua bidang hukum yang sulit untuk dipisahkan dan ditarik batasannya.

Namun, ada juga yang berpendapat bahwa hukum perlindungan konsumen merupakan bagian dari hukum konsumen yang lebih luas. Az. Nasution, misalnya, berpendapat bahwa "hukum konsumen yang memuat asas-asas atau kaidah-kaidah bersifat mengatur, dan juga mengandung sifat yang melindungi kepentingan konsumen.” Adapun, menurut Az. Nasution, yang dimaksud dengan hukum konsumen adalah "keseluruhan asas-asas dan kaidah-kaidah yang mengatur hubungan dan masalah penyediaan dan penggunaan produk barang dan/atau jasa, antara penyedia dan penggunanya dalam kehidupan bermasyarakat." Sedangkan mengenai hukum perlindungan konsumen didefinisikannya sebagai "keseluruhan asas-asas dan kaidahkaidah yang mengatur dan melindungi konsumen dalam hubungan dan masalah penyediaan dan penggunaan produk konsumen antara penyedia dan penggunanya dalam kehidupan bermasyarakat.” Selanjutnya, Az. Nasution mengakui, asas-asas dan kaidah-kaidah hukum yang mengatur hubungan dan masalah konsumen itu tersebar dalam berbagai bidang hukum, baik tidak tertulis maupun tertulis, seperti hukum perdata, hukum dagang, hukum pidana, hukum administrasi negara, dan hukum internasional terutama konvensi-konvensi yang berkaitan dengan kepentingan-kepentingan konsumen. Adapun yang masih belum jelas dari pernyataan Az. Nasution berkaitan dengan kaidah-kaidah hukum perlindungan konsumen yang senantiasa bersifat mengatur. Apakah kaidah yang bersifat memaksa, tetapi memberikan perlindungan kepada konsumen tidak termasuk dalam hukum perlindungan konsumen.

Berdasarkan hasil wawancara dapat dikemukakan bahwa nasabah sebagai konsumen memilki kedudukan yang lemah. Nasabah hanya bisa mengajukan klaim pada pihak bank. Transaksi dengan menggunakan electronic funds transfer sangat rentan terhadap timbulnya penipuan (fraud ) yang antara lain dapat dilakukan oleh nasabah atau pihak yang berhubungan 
dengan nasabah, pihak bank dalam hal ini adalah pegawai bank itu sendiri maupun dari transmisi telekomunikasi.

Faktor Penghambat Dalam Mekanisme Perlindungan Hukum Terhadap Nasabah Perbankan Dalam Praktik Transaksi Elektronik Berhubungan Dengan Tanggung Jawab Bank Atas Informasi Nasabah

Bank tidak bertanggung jawab untuk memperoleh tanda bukti penerimaan dari penerima uang. Namun bila hal tersebut diminta oleh pengirim maka bank akan mengusahakannya dengan dikenakan biaya yang dibebankan kepada pengirim. Dalam hal ini nasabah memiliki kedudukan yang lemah bila terjadi permasalahan dengan pihak bank, sebab pada ketentuan ini disebutkan bahwa bank tidak berkewajiban untuk memperoleh tanda bukti. Bank dapat mengusahakannya dengan biaya yang harus dibayar oleh nasabah. Apabila terjadi permasalahan, nasabah akan merasa kesulitan untuk mengajukan klaim ke pihak bank. Sehingga pemberian perlindungan hukum kepada nasabah belum dilakukan secara maksimal.

Penelitian berikutnya adalah tidak menutup adanya human error yang dilakukan oleh pegawai bank BNI itu sendiri, sehingga nasabah merasa dirugikan. Sebagai contoh pada saat nasabah ingin melakukan transfer dana, tidak menuup kemungkinan pihak bank BNI juga melakukan kesalahan sehingga dana yang seharusnya ditransfer tidak ada., hal ini jelas sangat merugikan nasabah.Nasabah kurang memperhatikan informasi yang jelas dan lengkap mengenai suatu produk perbankan. Informasi yang jelas dan lengkap merupakan hal yang penting bagi nasabah perbankan untuk memilih suatu produk perbankan, sebelum nasabah tersebut memutuskan dan menggunakan salah sau produk perbankan tersebut. Hal ini tidak sesuai dengan dalam UUPK Pasal 5 butir a dimana nasabah berkewajiban untuk membaca atau mengikuti petunjuk informasi dan prosedur pemakaian atau pemanfaatan barang dan / atau jasa demi keamanan dan keselamatan. Sikap nasabah yang kurang teliti terlihat pada saat nasabah tersebut mengisi aplikasi atau formulir. Dimana nasabah tidak membaca terlebih dahulu mengenai ketentuan dan persayaratan yang terlampir pada aplikasi atau formulir tersebut. Menurut UUPK Pasal 5 butir a dimana nasabah berkewajiban untuk membaca atau mengikuti petunjuk informasi dan prosedur pemakaian atau pemanfaatan barang dan / atau jasa demi keamanan dan keselamatan. Hal ini kadang - kadang tidak dilakukan oleh nasabah, sehingga mengakibatkan kerugian pada diri nasabah itu sendiri. Hal ini terkait dengan kedudukan nasabah yang lemah merupakan hal yang penting bagi nasabah perbankan untuk memilih suatu produk perbankan, sebelum nasabah tersebut memutuskan dan menggunakan salah satu produk perbankan tersebut. Hal ini tidak sesuai dengan dalam UUPK Pasal 5 butir a dimana nasabah 
berkewajiban untuk membaca atau mengikuti petunjuk informasi dan prosedur pemakaian atau pemanfaatan barang dan / atau jasa demi keamanan dan keselamatan.

\section{Simpulan}

Perlindungan hukum terhadap nasabah perbankan dalam praktik transaksi elektronikberhubungan dengan tanggung jawab bank atas keabsahan informasi nasabah adalah dengan mengendalikan risiko yang sudah diatur dalam peraturan bank Indonesia serta UndangUndang Informasi Transaksi Elektronik, selain itu mencegah agar tidak terjadinya kejahatan dalam elektronik dengan mengupayakan konsumen agar selalu update terhadap pembaharuan data nasabah. Sehubungan dengan tanggung jawab Bank sebagai penyedia Layanan Elektronik Banking ialah berdasarkan pada Peraturan Bank Indonesia No. 7/6/PBI/2005 tanggal 20 Januari 2005 tentang "Transparansi Informasi Produk Bank dan Penggunaan Data Pribadi Nasabah" sesuai dengan amanat dalam Undang-Undang No. 8 Tahun 1999 tentang Perlindungan Konsumen, menjaga keamanan serta pelayanan yang terbaik kepada nasabah. Jika didalam pelaksaannya hal yang menjadi tanggung jawab Bank tidak dapat dipenuhi, dan Bank memberikan kerugian terhadap nasabah. Maka pihak Bank akan memenuhi tanggung jawab dalam bentuk yang pertama, ganti rugi kepada Nasabah atas kerugian dan kealpaan yang dilakukan oleh pihak Bank dengan terlebih dahulu menindak lanjuti atas keluhan Nasabah atas kerugian yang di deritanya, dan apabila terbukti benar maka pihak Bank akan memenuhi pembayaran ganti rugi atas kerugian yang diakibatkan oleh Bank. Yang kedua, jika terbukti adanya keterlibatan pihak Bank atau oknum karyawan yang lalai yang mengakibatkan kerugian di pihak Bank, maka Bank berdasarkan kode etik memberikan tindakan atas kelalaian Karyawan tersebut yang mengakibatkan kerugian di pihak nasabah. Yang ketiga, apabila pihak Bank tidak mampu untuk memenuhi apa yang menjadi tanggung jawabnya atas kelalaian bank, maka atas ketidakmampuan Bank atas tanggung jawabnya maka Bank akan menerima sanksi atau konsekuensi atas reputasi dan kredibilitas Bank dalam tanggung jawabnya melindungi Nasabah.

Faktor penghambat dalam mekanisme perlindungan hukum terhadap nasabah perbankan dalam praktik transaksi elektronik berhubungan dengan tanggung jawab bank atas keabsahan informasi nasabah meliputi : dilihat dari sisi pelaku usaha, dimana pihak bank BNI tidak bertanggung jawab untuk memperoleh tanda bukti penerimaan dari penerima uang dan juga tidak menutup adanya human error yang dilakukan oleh pegawai bank BNI itu sendiri, dilihat dari sisi nasabah selaku konsumen, dimana nasabah kurang memperhatikan informasi yang jelas dan lengkap mengenai suatu produk perbankan dan juga sikap nasabah yang kurang teliti terlihat pada saat nasabah tersebut mengisi aplikasi atau formulir, dilihat dari sisi lain, kurang 
berperannya pihak-pihak yang terkait dengan perlindungan terhadap nasabah seperti Bank Indonesia, dan lembaga perlindungan konsumen

\section{DAFTAR PUSTAKA}

A.P.G, Wulanmas, Buku Ajar Hukum Perbnkan (Yogyakarta: Genta Press, 2011)

Brian Ami Prasetyo, 'Diskusi Permasalahan Hukum Terkait Internet Banking Dan Solusi Penyelesaiannya', Buletin Hukum Perbankan Dan Kebanksentralan, Vol.3 No.2 (2005), $65-66$

Budi Raharjo, Keamanan Informasi Berbasis Internet (Bandung: PT.Insan Indonesia, 2005)

Gunawan widjaja dan Ahmad Yani, Hukum Tentang Perlindungan Konsumen (Jakarta: PT.Gramedia Pustaka Utama, 2003)

Nasution, A.Z, 'Aspek Hukum PErlindungan Konsumen Tinjauan Singkat Undang - Undang No. 8 Tahun 1999', Media Hukum Dan Keadilan, Vol.II No. (2003)

Raditio, Resa, Aspek Hukum Transaksi Elektronik (Jakarta: Graha Ilmu, 2014)

Romli Atmasasmita, Teori Hukum Integratif ,Rekonstruksi Terhadap Teori HUkum Pembangunan Dan Teori Hukum Progresif (Yogyakarta : Genta Publishing, 2012)

Sudaryatmo, Hukum Dan Advokasi Konsumen (Bandung: PT.Citra Aditya Bhakti, 1999) 